\title{
The procedures manual: a guide for giving workshops
}

\section{El manual de procedimientos: una guía para la impartición de talleres}

\author{
DORANTES-BALDERAS, Magaly Abigail† \& GONZÁLEZ-HERRERA, Karina Concepción*
}

Universidad Tecnológica Metropolitana, Mexico.

ID $1^{\text {st }}$ Author: Magaly Abigail, Dorantes-Balderas / ORC ID: 0000-0003-4381-0313

ID $1^{\text {st }}$ Coauthor: Karina Concepción, González-Herrera / ORC ID: 0000-0002-1743-2614, Researcher ID Thomson: R3825-2018, CVU CONACYT ID: 256147

DOI: $10.35429 / E J R P .2020 .11 .6 .33 .41$

Received July 20, 2020, Accepted December 30, 2020

\begin{abstract}
The education has evolved and with it, it must be integrated towards to the students at professional level, the present investigation has as fundamental purpose the delimitation in scientific vocations for students of superior level, as well as the integration from certain processes according to a manual of processes, establishing the design, elaboration and impartation of formative workshops integrated to the vocation. The present work integrated the planning of the problems which big, medium, small and micro companies can present even if they do not have the document, as well as the purpose and importance of this in the internal and external part of the organizations. For economic units in education services registered in Mexico, micro companies represent the majority and the rest are classified as small, while medium and large organizations represent a small percentage. The school modality says that the professional level can be classified from the highest technical level and that only a percentage of them continues their studies at the degree level. For the research, the methodology is identified by integrating the instrument applicable to teachers who will give the formative workshops by knowledge of the cathedra.
\end{abstract}

Educational, Manual processes, School modality

\begin{abstract}
Resumen
La educación ha evolucionado y junto con esta debe estar integrada con los estudiantes en nivel profesional, la presente investigación tiene como propósito fundamental la delimitación en vocaciones científicas para estudiantes de nivel superior, así como también la integración a partir de ciertos procesos conforme a un manual de procedimientos, estableciendo el diseño, elaboración e impartición de talleres formativos integrados a la vocación. El presente trabajo integra la planeación de los problemas las cuales grandes, medianas, pequeñas y micro empresas pueden llegan a presentar por no contar con el documento, así como también el propósito e importancia de este en la parte interno y externa de las organizaciones. Para las unidades económicas en servicios educativos registradas en México, las empresas micro representan la mayor parte y el restante están clasificadas como pequeñas, mientras que las organizaciones medianas y grandes representan un pequeño porcentaje. La modalidad escolarizada dice que el nivel profesional es clasificable desde el nivel técnico superior y que solamente un porcentaje de este continua sus estudios a nivel licenciatura. Para la investigación se identifica la metodología integrando el instrumento aplicable a profesores los cuales darán indicio a el taller formativo por conocimiento de cátedra.
\end{abstract}

Educación, Manual de procesos, Modalidad escolarizada

Citation: DORANTES-BALDERAS, Magaly Abigail \& GONZÁLEZ-HERRERA, Karina Concepción. The procedures manual: a guide for giving workshops. ECORFAN Journal-Republic of Peru. 2020. 6-11:33-41.

\footnotetext{
* Correspondence to Author (Email: karina.gonzalez@utmetropolitana.edu.mx)

$\dagger$ Researcher contributing first author.
} 


\section{Introduction}

The manual according to (Herrera, Valero, \& Gallego, 2010) in a clear and short concept is expressed as "the instrument built by the subject that needs to be addressed". After inquiring into authors, it can be said that the manual is a guide that serves as a tool when it comes to wanting to integrate different instructions for a purpose in compliance that is to say that it contributes to a function for a better order, clarity and always with an objective in set.

For the realization of a procedures manual and to know the context, it was investigated with (Secretary of Foreign Relations [SER], 2004) which indicates that the procedure manuals "are administrative instruments that support the institutional work and are considered as fundamental documents for the coordination, direction, evaluation and administrative control, as well as for consultation in the daily development of activities".

The point of view is identified (Rusenas, 1999) that sustains that the manuals: Contain information on the set of operations or stages that are established chronologically to carry out a certain type of work. They are also known by the name of operation manuals, standard practice, introduction to the work of procedures and work methods (p.1)

But there are different types of manuals (see image 1), depending on their content, scope or recipients.

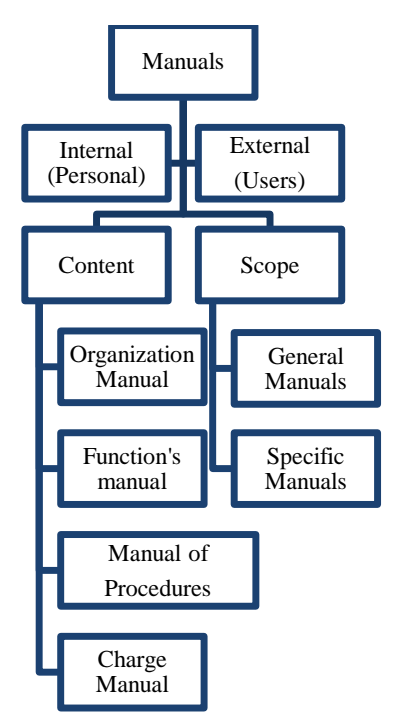

Figure 1 Classification of manuals according to (Pintos, 2009)

Source: self made
It is important to note that the different institutions prepare manuals according to their needs and requirements.

This document presents the elements considered for the elaboration of instruction guide manuals for a decentralized public educational institution, which exceeds 250 collaborators and is located in the city of Mérida, Yucatán, with infrastructure located in the south of the city. The manuals are generated as a result of actions aimed at establishing mechanisms to promote research, education and science.

\section{Problem Statement}

At present, small companies present problems and / or conflicts by not having a manual, which, as mentioned above, specifies each and every one of the operations carried out within an organization, which can be divided into areas, departments, such as they are those of operations, sales, security, pre-opening guide, human resources, among others.

Contributing to the point of view, the author (Vásquez, 2016) comments that by not having influence that lies in a manual: The chances of making some type of error that usually occur within the functional areas of the company are greater. Causing major failures that appear regularly, avoiding duplication of functions. In addition, it would be even more complicated when new people enter the organization since in large part everything related to it is explained, from its historical review, making reference to its organizational structure, to explaining the procedures and tasks of certain (p .25).

In the absence of a manual eradicated to its function or policies, (Mutzenbecher, 2006) specifies that there are a series of variables that affect the development of internal operations, these are: "The absence of information clearly established on the objectives, functions and responsibilities of each person in any operational area. In addition to not assuming parameters for decision-making, as well as limits for other members". 
Regarding external factors, (Cariño, 2007) explains that: Without efficient management of resources together with the objective to which it is destined, the required quality would be complicated, everything suggests the need to have an adequate structure to the needs of the company that can help it to have a management not only in writing but also of its operation by coordinating with its specific purpose (p.1).

This tool must be clear and within the reach of anyone interested in knowing in detail the structure that a manual entails, being by organization that for this it is adapted to the needs and capacities, giving its content and the theoretical and practical support that it can provide to the functions and operations to which it is intended.

\section{Justification}

The elaboration has great importance in the current era, many companies direct their efforts in the generation of benefits for the development administration with the tool that its structure allows, for (Burgos \& Quinapallo, 2016): It leads as a valuable aid for the monitoring and continuous improvement of processes. [...] It is confirmed that the procedure manuals represent for companies a tool for consultation, review, analysis and restructuring of their key and support processes that in many cases facilitate the obtaining of national and international quality certifications (p. 1- 2). The main purpose of the manual of processes or procedures is to serve as a support for the development of actions, that is why it is based on a process operation model, which allows managing the public entity as a whole, defining the activities that add value, work as a team and have the necessary resources for its realization.

For this reason (Muñoz, 2007) mentions that its importance lies as: A model of operation by processes favors, the fulfillment of the principles of responsibility, by defining the macro processes and processes in accordance with the constitutional and legal precepts, the mission and vision Of the entity; economics, by precisely identifying the inputs for each process with the required quality and quantity conditions; efficiency, by avoiding duplication of functions; and efficiency, by defining the value chain or process map in a coherent and harmonious way with the Institution's plans and programs (p.4).
For this, and in accordance with what is stated (Muñoz, 2007), the main purposes of a procedures manual are: Define the operating parameters of each process, its activities and tasks, guaranteeing compliance with the objective of the macro-process to which it belongs and contributes. As well as defining the information flows to comply with the objectives of the activities necessary for the proper management or operation of the entity. In addition to establishing the levels of authority, responsibility required in the execution of the actions inherent to the operation of the entity, channeling the resources and institutional capacities required in carrying out the processes (p.12).

Something similar happens when the procedures manual becomes a formal or official guide for the execution of a certain process that allows to clearly know what, how, when and where it should be done, also knowing the necessary resources and requirements.

In order to take the various authors into account, it can be considered that the importance lies in their content, which was explained in this segment in a concise and detailed manner, the follow-ups within and guidelines outside an organization, since by understanding that through them, achieves compliance with the objective, this by avoiding large functional errors that may occur in the process.

\section{Economic units in educational services}

With respect to the total national economic units (EU) registered in Mexico, as shown in the table, micro companies represent $95 \%$ and the remaining $5 \%$ are classified as small, while medium and large organizations represent less than $1 \%$, that means that in the country the highest percentage is concentrated in micro companies and the lowest in medium and large ones. For the educational services approach (SE) in Mexico it represents 3\% in economic units and has the micro units that are $52 \%$, the small ones $37 \%$, the medium ones $9 \%$ and the percentage difference equivalent to $2 \%$ in the big. At the level of the Yucatan Peninsula, there is a $4.4 \%$ EU registry, which is made up of $49 \%$ of micro companies, $39 \%$ of small ones, $10 \%$ equivalent to medium-sized companies and $2 \%$ in large companies. 
In Yucatan it has more than half of the EU of the peninsula since it represents $54 \%$ of them, they are distributed with a higher percentage in the micro with $97 \%$ and the remaining $3 \%$ in the small ones while with less than $1 \%$ they are medium and large companies. (see table 1).

\begin{tabular}{|c|r|r|r|r|r|}
\hline \multicolumn{1}{|c}{ Micro } & \multicolumn{1}{c}{ Little } & \multicolumn{1}{c|}{ Median } & \multicolumn{1}{c|}{ Big } & \multicolumn{1}{c|}{ Total } \\
\hline EU Mexico & $5,119,909$ & 247,912 & 82,035 & 37,205 & $5,367,821$ \\
\hline From Mexico & 82,213 & 58,054 & 14,832 & 2,700 & 157,799 \\
\hline SE Peninsula & 3,435 & 2,755 & 658 & 137 & 6,985 \\
\hline OF Yucatan & 1,965 & 1,444 & 312 & 71 & 3,792 \\
\hline
\end{tabular}

Table 1 Geographical context of educational services in Mexico

Source: own elaboration based on (National Institute of Statistics and Geography [INEGI], 2020)

For the field worked, higher level students are required for (Secretary of Public Education [SEP], 2019):

It is the type of education that is imparted after upper secondary education; It is made up of levels: university or associate professional technician, bachelor's, specialty, master's and doctorate, as well as normal education in all its specialties. The typical age group for this type of education is 18 to 23 years old (p.7).

\begin{tabular}{|l|c|c|c|}
\hline \multicolumn{5}{|c|}{ School modality } \\
\hline $\begin{array}{l}\text { Type of } \\
\text { service and } \\
\text { support }\end{array}$ & $\begin{array}{l}\text { Total } \\
\text { Students }\end{array}$ & Teachers & Schools \\
\hline $\begin{array}{l}\text { Higher } \\
\text { education }\end{array}$ & $3,943,544$ & 414,408 & 5,535 \\
\hline Normal & 91,978 & 14,480 & 408 \\
\hline $\begin{array}{l}\text { Bachelor's } \\
\text { degree }\end{array}$ & $3,610,744$ & 333,617 & 4,502 \\
\hline Postgraduate & 240,822 & 66,311 & 2,459 \\
\hline Public & $2,773,338$ & 243,341 & 2,283 \\
\hline Private & $1,170,206$ & 171,067 & 3,252 \\
\hline
\end{tabular}

Table 2 Enrollment context registered at the national level Source: (Secretary of Public Education [SEP], 2019)

With respect to the previous table, the normal and undergraduate level are reflected with $93.9 \%$ and only $6.1 \%$ continue their studies with a postgraduate degree. In the case of sustainability, it is shown that the public acquired $70.3 \%$ and the private with $29.7 \%$. Among them are state public universities, polytechnics, technological institutes, federal public universities and technological universities.
In the case of the latter, a curricular model is supported, that is, it is necessary to specify and encompass the policies and guidelines to which the consolidation of technological universities is subject. For (Secretary of Public Education [SEP], 2019) "this model maintains the intrinsic characteristics of the Higher University Technician and makes its curricular structure more flexible to be able to offer students lateral exits towards the Bachelor's level" (p. 4).

\section{Methodology}

As a starting point, the methodology for (Gomez, 2012) defines it "as the treatise or science of methods. It is the discipline made up of procedures, instruments, and techniques that allow us to reach knowledge in the field of scientific research" (p.85).

It can be argued that the methodology is part of a logistics that studies the set of methods that follow an investigation or a study to which you want to provide a solution in analysis, field and result in order to achieve the objective or objectives that govern a deep obtaining information.

In addition to indicating the research approaches seen as processes; quantitative, qualitative and mixed methods (Hernández, Fernández, \& Baptista, 2014):

The quantitative approach represents a set of sequential and probative processes, has characteristics of bounded approaches, measures phenomena, uses statistics, hypothesis testing and theory. In addition to allude to a deductive, sequential, probative process and with an analysis of objective reality. One of its sections on benefits is the generation of results, control over phenomena and prediction.

The qualitative approach has characteristics of its more open approaches that are focused, it is conducted basically in natural environments and the meanings are extracted from the data. We work with the qualitative research approach, which describes the elements that make up the manuals and the process that was followed for the orientation of the teachers and researchers who worked on the materials. Subsequently, an instrument that is described below was applied. 


\section{Instrument}

The instrument that was used is the interview being designed to obtain information, the previous one is made up of a dialogue between two subjects, questions of interest are formulated which are expected to be answered by the interviewee. It is a technique used to maintain a conversation on a common topic. The interview was carried out in order to know information from the internal and external part of each branch under study towards a vocation, it is important to mention that the instrument conforms a greeting to the teacher, a personal presentation of the interviewer, an introduction summary for the subject matter and the purpose of the information provided.

The training workshops from which the materials that support the instruction (manuals) are derived, are associated with the development of competencies that with practice will be perfected, because it is the first time that an event was held in the university subject of study that would strengthen scientific competencies. Derived from a subject, it is stated by (SalasGutiérrez, 2020) that "the challenges are always how to generate increasingly relevant and meaningful experiences that contribute to strengthening these skills, and partly overcome the feelings of anxiety, insecurity and frustration that they experience many students when faced with these assignments "(p. 53), in relation to the above, the sustenance of the research is classified as tedious, tiring, boring and among others, which is why the manuals sought to present in an accessible way, activities, examples and exercises associating it with the proposed guide.

\section{Analysis of results}

The results achieved are presented below, based on the implementation of the design of the instruction manuals (see figure 1 and figure 2):

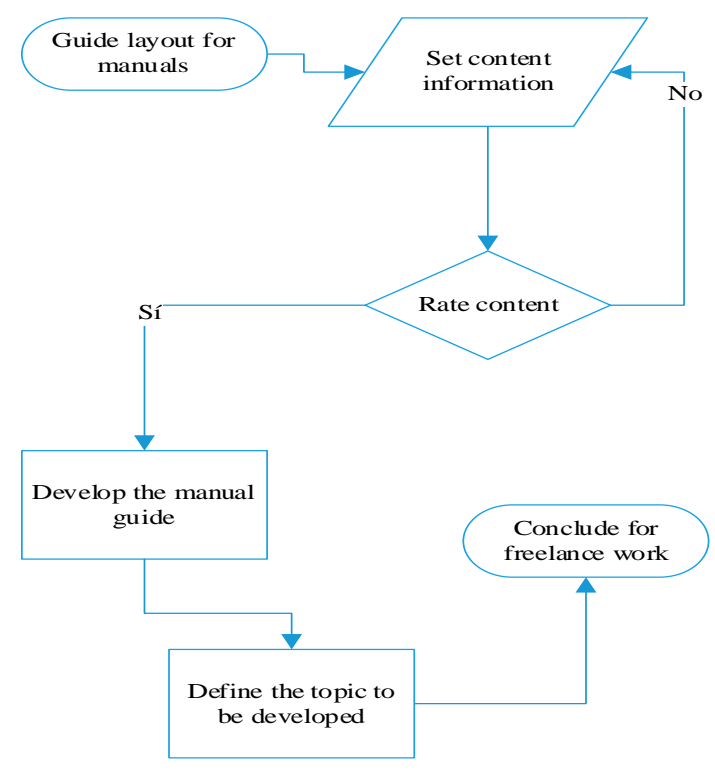

Figure 1 Process to establish the format of the manuals Source: Self made

Once the topic to be developed was defined and the content of the manuals, the manuals were prepared by the professor and researcher, considering the following elements:

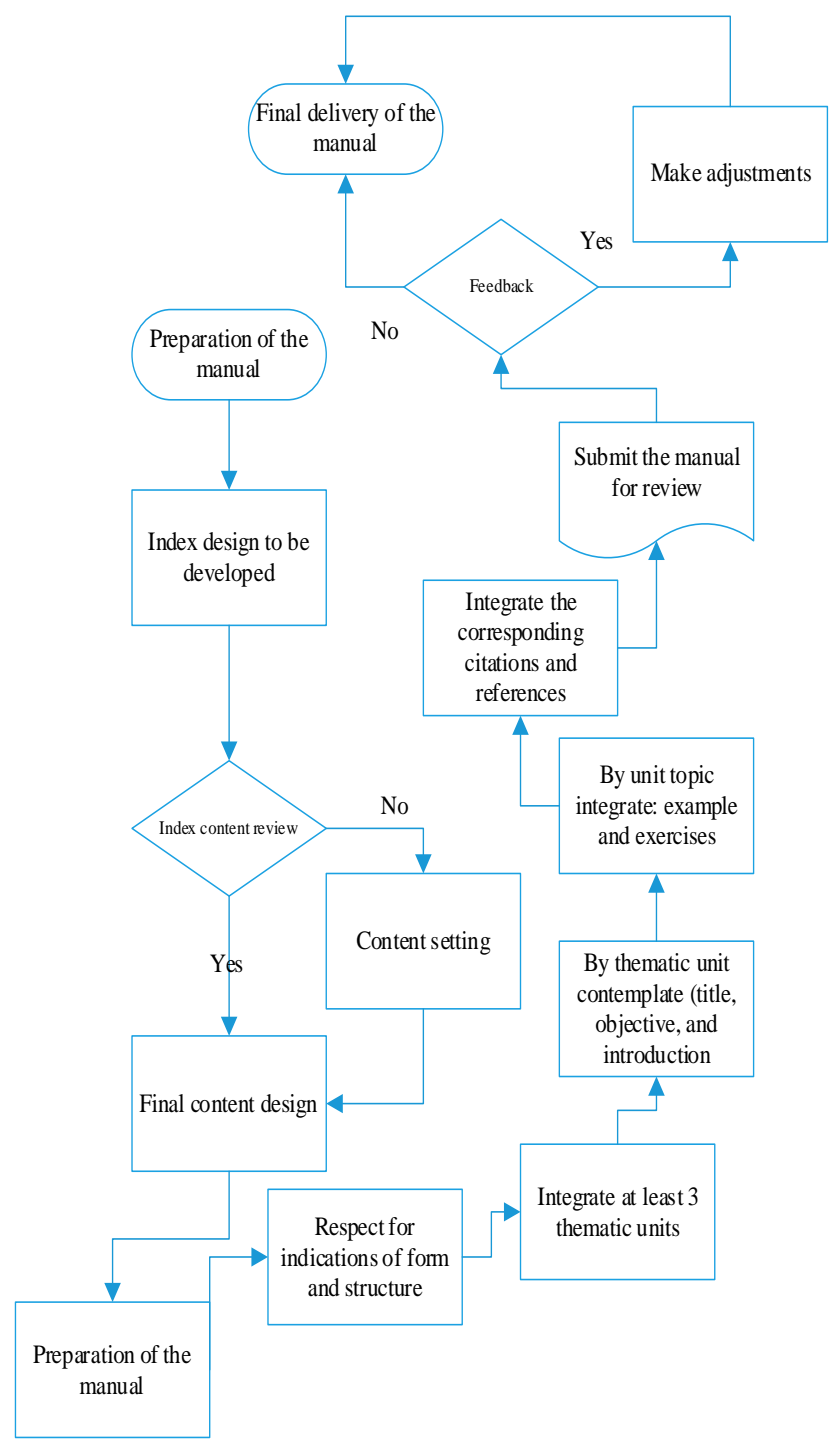

Figure 2 Contents and elements of the manual Source: self made

DORANTES-BALDERAS, Magaly Abigail \& GONZÁLEZ-HERRERA, Karina Concepción. The procedures manual: a guide for giving workshops. ECORFAN Journal-Republic of Peru. 2020 
Once the manuals were approved, the materials were transferred to the virtual platform to be studied.

For the design of the manuals, there was a virtual meeting where the content of these was shared with the professors and researchers who would have the commitment to produce the guide materials, as mentioned (Serrano Anton, et al., 2020) "el calendar includes an initial meeting and distribution of tasks; sharing of jobs once a month; and the preparation of a final report through a speaker and review by all its members" (p. 8).

Next, the professors and researchers were invited to respond to the designed interview, which allows them to have a referent of the subject by scientific vocations, evaluating the way of seeing the purpose of the program, also seen towards the professional objectives that can lead to own.

Two weeks were available for the application of the interviews, after programming with the study subjects, which had the following order:

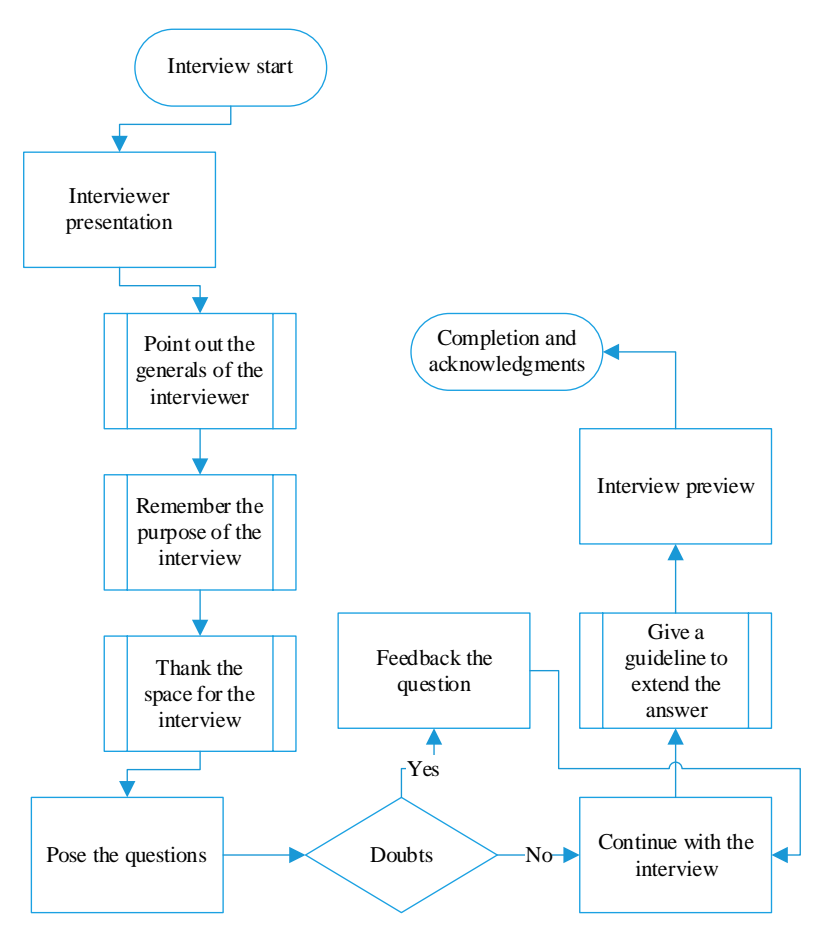

Figure 3 Interview process Source: Self made
For the week of applying the interviews, an approach to the subject was presented, trying to relate the questions to the training workshop; As the first one addressed to the subject of study in question, it was made referring to their work for years working in an institution, specifically to the question, as a result it was obtained that most have an antiquity of more than 10 years except for one who is or is is about to fulfill them.

In the second question, it deals with institutions in which the study subjects have collaborated to impart their knowledge in addition to the current one; all the professors clarified having worked in other institutions, as well as having been director of an institution or in external positions to teach.

The third question is more related to the content of your classes by commenting on the way it encourages research and what you think is the reason why most of a generation is not in the habit of doing it. The first person claims to carry out activities that invite them to investigate or search and select their sources of information, in addition to the fact that he comments that the reason for the lack of interest is because they do not have guidance from an early age. The next person begins by investigating simple things in their classes, then completes it with an induction to select students who notice enthusiasm for scientific topics and support them in their development. The third person works only with what is supported by her students and believes that the reason why it is not investigated is because of the social structure as it is not instilled from home. The following person tells me that she works with a scientific approach in her tasks, concluding that research has to be stimulated and motivated from other levels than the higher one. For the doctor who works in the incubator, she talks about programs to encourage teachers, thus transmitting to the students the importance of investigating great authors. The rest of the teachers give me their point of view very similar to what was written previously. 
In relation to continuing with the topic, they are asked how they contribute in their classes to the investigation and correct citation, the first professor tells me that he contributes with rigorous revisions in the content of the information and correct citation. For the next subject of study in his investigations he asks that they be sources with scientific value, in addition to knowing how to quote correctly is a mandatory class session as an indication. In the following interview due to lack of time, he comments that he only contributes to that topic when requesting tasks with bibliography correctly. The subject of the next study asks for a level of demand, since it is a university level and the one correctly quoted is included. The teacher informs me that when she taught, she demanded to read and paraphrase any task imposed by her, thus forcing them to handle the rule of respecting the author and the requested format. On the other hand, the following professor contributes by inviting students to get involved in an investigation in which they may be interested and in which the University is a part. Later with the last subject of study she tells me that in any subject to be developed in her class model there is at least one investigation.

To continue with questions number 7 these were the answers, in the first part they tell me that sometimes teachers do not see the passion for teaching or do not follow up on their tasks, on the other hand, the most common error in students is copying information which it is not true. The next teacher comments as a mistake not reading all the papers, also another mistake is that they do not try to make their classes dynamic, on the part of the students is not taking the trouble to study at home or verify their sources. For the following, the mistake falls on the teachers when they do not read the learning objective according to the characteristics of the investigation, other mistakes are to provide the student with something that should be their responsibility. With regard to mistakes in students, she says that they do not know the educational program. Another point of view is that all teachers make up their subject according to their professional profile and a subject. For the doctor who works in another area, she comments that the teachers to a great extent have poor planning, in the students the error is in reading sources that do not contribute.
For the next teacher, what can affect both parts is the absence of information diverted by excess spaces, documents and data on the internet. For the last teacher, she mentioned that the errors are consistent with previous teachers since to a large extent it is made up of the virtual settings and the social networks associated with this.

\section{Conclusions}

In conclusion, it can be mentioned that the procedure manual is important, when there is a structured guide for the own design that allows to achieve the desired results according to the results that are intended to be achieved with it, although the study subjects mentioned data of great value, it is important to note that in the end not all were able to conclude with the design of the instructional guide document. However, it should be noted that the workload associated with the responsibilities assumed prevents the expected results from being achieved.

On the other hand, stimulating research through simple techniques and clearly established mechanisms is a task that not all teachers can transmit, in such a way that as teachers, researchers and others are updated, it has the task of guiding they will be able to promote better results in and towards the student body and mainly in higher level students.

\section{References}

Burgos, R. A., \& Quinapallo, G. C. (2016). IMPORTANCIA DE LOS MANUALES DE PROCEDIMIENTOS PARA LA MEJORA DE LOS PROCESOS OPERATIVOS EN LAS AGENCIAS DE ADUANAS. CARIBEÑA DE CIENCIAS SOCIALES, 13. Recuperado el 14 de Junio de 2020, de https://www.eumed.net/rev/caribe/2016/10/adu anas.html

Cariño, S. A. (2007). Propuesta de Reestructuración Organizacional para la empresa Vegetales Selectos de Puebla. Puebla, México. Recuperado el 09 de Junio de 2020, de http://catarina.udlap.mx/u_dl_a/tales/document os/lad/carino_s_al/ 
Gomez, B. S. (2012). Metodología de la investigación. Estado de México: RED TERCER MILENIO S.C. Recuperado el 25 de Julio de 2020, de http://www.aliat.org.mx/BibliotecasDigitales/A xiologicas/Metodologia_de_la_investigacion.pd $\mathrm{f}$

González, L. J., \& Ruiz, H. P. (Septiembre de 2011). Investigación cualitativa versis cuantitativa: ¿dicotomía metodológica o ideológica? Index de Enfermería(3). doi:http://dx.doi.org/10.4321/S113212962011000200011

Hernández, S. R., Fernández, C. C., \& Baptista, L. M. (2014). METOLOGÍA DE LA INVESTIGACIÓN (Sexta ed.). México D.F: McGRAW-HILL / INTERAMERICANA EDITORES, S.A. DE C.V. Recuperado el 25 de Julio de 2020, de http://observatorio.epacartagena.gov.co/wpcontent/uploads/2017/08/metodologia-de-lainvestigacion-sexta-edicion.compressed.pdf

Herrera, F. L., Valero, V. J., \& Gallego, B. A. (2010). Medición del momento de inercia de un anillo y un disco implementado acelerómetro en una mesa ratatoria. Scientia et techinica, 180185.

doi:

http://dx.doi.org/10.22517/23447214.371

Instituto Nacional de Estadística y Geografía [INEGI]. (Abril de 2020). Directorio Estadístico Nacional de Unidades Económicas. INEGI. Obtenido

https://www.inegi.org.mx/app/mapa/denue/

Muñoz, A. B. (2007). IMPORTANCIA DE LA IMPLEMENTACIÓN DEL MANUAL DE PROCESOS Y PROCEDIMIENTOS PARA EL LOBRO DE LOS OBJETIVOS DE LAS ESCUELAS POPULARES DEL DEPORTE PERTENECIENTES AL INSTITUTO D EDEPORTES $Y$ RECREACIÓN DE MEDELLÍN, INDER. UNIVERSIDAD DE ANTIOQUIA INSTITUTO UNIVERSITARIO DE EDUCACIÓN FÍSICA MEDELLÍN. Recuperado el 14 de Junio de 2020, de http://viref.udea.edu.co/contenido/pdf/084importancia.pdf
Mutzenbecher, M. C. (2006). Diagnóstico y Propuesta de Solución a un Problema: "Establecimiento Inadeacuado de Políticas". Cholula, Puebla, México: the Special Events Planners S.A. de C.V. Recuperado el 09 de Junio de 2020, de http://catarina.udlap.mx/u_dl_a/tales/document os/lni/mutzenbecher_m_c/capitulo2.pdf

Pintos, T. G. (2009). Los manuales administrativos hoy. Facultad de Ciencias Económicas y de administración. Departamento de ciencias de la administración cátedra de organización y métodos administrativos. Recuperado el 02 de Junio de 2020, de https://aplicaciones.onsc.gub.uy/pmb/opac_css/ doc_num.php?explnum_id=71

Sánchez-Gutiérrez, B. (2020). “Conociéndome a través de mi comunicación interpersonal" Taller desde el enfoque centrado en la persona de Carl Rogers, con servidores públicos del Organismo Coordinador de la Operación Integral del Servicio de Transporte Público del Estado de Jalisco.Rusenas, R. O. (1999). Marco teórico sobre: manual, procedimientos, control interno, cuentas por cobrar y factoraje. En G. Quiroga Leas, Organización y métodos en la administración pública. México: Editorial Trillas. Recuperado el 02 de Junio de 2020, de http://ri.ufg.edu.sv/jspui/bitstream/11592/7098/ 3/657.458-M722m-Capitulo\%20II.pdf

Secretaria de Educación Pública [SEP]. (2019). PRINCIPALES CIFRAS DEL SISTEMA EDUCATIVO NACIONAL. México: Dirección General de Planeación, Programación y Estadística. Recuperado el 23 de Junio de 2020, de

https://www.planeacion.sep.gob.mx/Doc/estadi stica_e_indicadores/principales_cifras/principal es_cifras_2018_2019_bolsillo.pdf

Secretaria de Relaciones Exteriores [SER]. (2004). GUÍA TÉCNICA PARA LA ELABORACIÓN DE MANUALES DE PROCEDIMIENTOS. México: DIRECCIÓN GENERAL DE PROGRAMACIÓN, ORGANIZACIÓN Y PRESUPUESTO. Recuperado el 02 de Junio de 2020, de https://www.uv.mx/personal/fcastaneda/files/20 10/10/guia_elab_manu_proc.pdf 
Serrano Anton, F., Conde Pérez, E., Haro Izquierdo, M. D., Puyol Montero, J. M., MartínCaleroGastaminza, R., \& Rodríguez Ortega, I. (2020). Elaboración de una Guía Docente para la enseñanza de asignaturas en inglés en el Grado de Derecho. Madrid, España. Recuperado el noviembre de 2020, de https://eprints.ucm.es/62332/1/Memoria\%2023 0 -

2020\%20Gu\%C3\%ADa\%20\%20Docente $\% 20$ $\%$ 20revisada.pdf

Vásquez, M. A. (2016). Importancia de la implementación de un manualde atención al cliente en la empresa de materiales de construcción y ferreteros CONSTRUNORTE en la ciudad de Estelí en el segundo semestre del año 2015. Estelí: UNIVERSIDAD NACIONAL AUTÓNOMA DE NICARAGUA. Recuperado el 09 de Junio de 2020, de https://core.ac.uk/download/pdf/53104347.pdf 